\title{
HUBUNGAN KANDUNGAN NITRAT DAN FOSFAT DENGAN DENSITAS ZOOXANTHELLAE PADA POLIP KARANG Acropora sp. DI PERAIRAN TERUMBU KARANG PULAU MENJANGAN KECIL, KARIMUN JAWA
}

\author{
Tumpal H Pangaribuan, Churun Ain, Prijadi Soedarsono ${ }^{1}$ \\ Program Studi Manajemen Sumberdaya Perairan, Jurusan Perikanan \\ Fakultas Perikanan dan Ilmu Kelautan, Universitas Diponegoro
}

\begin{abstract}
ABSTRAK
Terumbu karang merupakan ekosistem pesisir yang memiliki produktivitas tinggi. Nutrien merupakan salah satu faktor penentu terpeliharanya produktivitas perairan. Adanya asumsi ketersediaan cahaya, keberadaan zooxanthellae dan nutrien menjadi faktor yang penting. Permasalahannya adalah, apakah dukungan ini didapatkan dari ketersediaan nutrien di lingkungan perairan atau di dalam polip karang. Terkait dengan hal tersebut, maka penelitian ini akan mempelajari dukungan nutrien di dalam polip karang dan pengaruhnya terhadap keberadaan zooxanthellae. Tujuan penelitian ini untuk mengetahui kondisi penutupan karang di daerah pulau Menjangan Kecil, mengetahui total nitrat dan total fosfat, densitas zooxanthellae, hubungan kandungan antara total nitrat dan total fosfat terhadap densitas zooxanthellae di polip karang Acropora sp. di perairan terumbu karang pulau Menjangan kecil, Karimun Jawa. Metode yang digunakan adalah metode deskriptif eksplanatif. Hasil penelitian menunjukkan bahwa penutupan karang di perairan pulau Menjangan Kecil stasiun I 73,6\% kategori baik dan stasiun II 76\% kategori sangat baik. Terdapat hubungan antara kandungan nitrat dan fosfat pada polip karang Acropora sp. dengan densitas zooxanthellae.

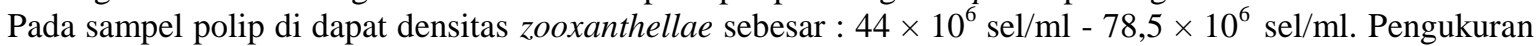
nitrat pada sampel polip di dapat hasil sebesar: $14,78 \%-21,09 \%$. Pengukuran kandungan fosfat, pada sampel polip di dapat hasil sebesar: $23,4 \%-28,18 \%$. Nilai koefisien determinasi $\mathrm{R}^{2}$ antara total nitrat dengan densitas zooxanthellae sebesar 0,939 dimana mengandung pengertian pengaruh total nitrat terhadap densitas zooxanthellae adalah 93,9 \% . Koefisien determinasi $\mathrm{R}^{2}$ antara total Fosfat dengan densitas zooxanthellae sebesar 0,514 dimana mengandung pengertian pengaruh total fosfat terhadap densitas zooxanthellae adalah $51,4 \%$. Hal ini mengindikasi semakin tinggi kandungan nitrat dan fosfat maka semakin tinggi pula densitas zooxanthellae di dalam polip karang Acropora sp. dan parameter kualitas air diukur sebagai data pendukung.
\end{abstract}

Kata kunci: Nitrat dan Fosfat, Densitas zooxanthellae, Acropora sp, Pulau Menjangan Kecil.

\begin{abstract}
Coral reefs are coastal ecosystem which containing high productivity. One of the main factors productivity is nutrient. The main factors for productivity are availiability of light, existence of zooxanthellae and nutrient the avaibiality of nutrient on water or inside coral polyps. Became the main issue for the research. The aim of the research is avaibility of nutrient in coral polypa is againts zooxanthellae. The purpose of the research was obtaining the condition of covering coral reefs in Menjangan Kecil Island, the total of the nitrate and phosphate, the data of zooxanthellae density and the correlation between total nitrate and phosphate and zooxanthellae in the water of the coral reffs of Menjangan Kecil Island, Karimun Jawa. The methods used in this research is descriptive methods explanative. The results showed that the closure of the coral in the water of Menjangan Kecil station I 73,6\% category good and category II station 76\% very good. There are relations between the contect of nitrate and phosphate in coral polyp Acropora sp. with the density of zooxanthellae. On sample of polyps in the zooxanthellae densities can rate: $44 \times 10^{6} \mathrm{sel} / \mathrm{ml}-78,5$ $\times 10^{6} \mathrm{sel} / \mathrm{ml}$. For measurements on a sample of nitrate can result in polyp rate: $14,78 \%-21,09 \%$. For measurements on a sample of phosphate can result in polyp rate: $23,4 \%-28,18 \%$. In the determination of the coefficient $\mathrm{R}^{2}$ value can be between total nitrate with density of zooxanthellae 0,939 . Contains the influence of nitrates on the sense the density of zooxanthellae was $93,9 \%$. The determination of the coefficient $\mathrm{R}^{2}$ value can be between total phosphate with density of zooxanthellae 0,514 . Contains the influence of nitrates on the sense the density of zooxanthellae was $51,4 \%$. This indicates the higher the nitrate and phosphate content of the higher density of zooxanthellae in the coral polyp Acropora sp. and water quality parameters measured as supporting data.
\end{abstract}

Kata kunci: Nitrate and Phosphate, Density of Zooxanthellae, Acropora sp, Menjangan Kecil Island. 


\section{Pendahuluan}

Taman Nasional Karimun Jawa (TNKJ) merupakan salah satu daerah perikanan artisanal (tradisional) penting di Laut Jawa, dengan 64 genera karang dan 353 spesies ikan karang, karimun Jawa merupakan salah satu kawasan yang dapat mewakili kondisi terumbu karang dengan kategori baik dari kawasan barat Indonesia. Pulau Menjangan Kecil merupakan pulau yang terletak di kepulauan Karimunjawa, memiliki luas daratan sekitar 64 ha. Secara administrasi Pulau Menjangan Kecil termasuk dalam zonasi pariwisata dan budidaya. Menjangan Kecil merupakan pulau yang memiliki pantai yang berpasir putih dengan ekosistem terumbu karang. Topografi dasar rataan terumbu berupa karang bercabang yang berkelompok dan tidak berkelompok, baik hidup maupun mati. Selain itu juga terdapat beberapa karang masif hidup dan mati dengan ukuran yang bervariasi. Beberapa jenis gastropoda dan bulu babi juga dijumpai pada daerah ini (Suharsono, 1996).

Ekosistem terumbu karang mempunyai produktivitas yang tinggi, karena ditunjang oleh keanekaragaman jenis karang dan biota yang tinggi. Selain itu secara tidak langsung karang dapat berfungsi sebagai penahan abrasi pantai, sebagai tempat makan biota laut, ketersediaan cahaya dan keberadaan zooxanthellae disinyalir menjadi unsur penting dalam memelihara produktivitas perairan. Meskipun kandungannya mutlak diperlukan untuk menjamin produktivitas terumbu karang, akan tetapi keberadaan nutrien diduga juga menjadi unsur pendukung hal tersebut. Permasalahan nutrien bagi karang menjadi faktor yang perlu dipelajari secara seksama. Hal ini disebabkan karena unsur ini menjadi faktor yang diperlukan zooxanthellae, serta plankton yang hidup di badan perairan.

Tujuan penelitian ini yaitu untuk mengetahui persentase penutupan karang di daerah pulau Menjangan Kecil, mengetahui total nitrat dan total fosfat di polip karang Acropora sp, mengetahui densitas zooxanthellae di polip karang Acropora sp dan mengetahui hubungan kandungan antara total nitrat dan fosfat terhadap densitas zooxanthellae di polip karang Acropora sp. Penelitian ini dilaksanakan pada bulan Juni sampai dengan bulan Juli 2013 di Pulau Menjangan kecil, Pulau Karimun Jawa, Jepara. Hasil penelitian ini diharapkan dapat memberikan masukan dan informasi mengenai pengaruh kandungan nitrat serta posfat pada polip karang terhadap evaluasi produktivitas terumbu karang dan diharapkan dapat menjadi acuan dalam pengelolaan terumbu karang yang lebih lanjut terhadap rekayasa transplantasi karang untuk rehabilitasi buatan demi kelestarian ekosistem terumbu karang.

\section{Materi dan Metode Penelitian}

A. Materi Penelitian

Materi yang digunakan dalam penelitian ini adalah nutrien dan zooxanthellae pada polip karang Acropora sp, dan beberapa variabel kualitas air. Alat yang digunakan dalam penelitian ini meliputi alat pengambilan sampel, alat pengukuran parameter kimia \& fisika dan alat uji laboratorium. Untuk alat pengambilan sampel meliputi : rol meter, skin dive, GPS, martil dan bethel, botol sampel, cool box, kamera bawah air, sabak dan alat tulis. Untuk alat pengukuran parameter kimia \& fisika meliputi : DO meter, refraktometer, pH Paper, piringan secchi disk, tongkat kedalaman, termometer, current meter. Untuk alat uji laboratorium meliputi: centrifiuge, haemocytometer, mikroskop opticlab, glass beaker $250 \mathrm{ml}$, mortal dan alu, pipet tetes, timbangan elektrik, kertas saring, erlenmeyer dan spectrophotometer.

\section{B. Metode Penelitian}

Metode yang digunakan dalam penelitian ini adalah metode deskriptif eksplanatif. Metode deskriptif eksplanatif yaitu metode yang digunakan untuk mengetahui kondisi atau aspek penelitian yang akan diteliti secara umum dan ingin meneliti lebih mendalam serta untuk mendapatkan gambaran lebih mendalam dari objek penelitian yaitu sampai mengetahui hubungan sebab akibat dari objek penelitian, Untuk mengarahkan kepada metode dan tujuan penelitian, akan dilakukan beberapa tahapan penelitian (Basmi, 1999).

\section{Pemilihan lokasi}

Pemilihan lokasi menggunakan studi pertimbangan (purposive sampling method) yaitu menentukan lokasi pengambilan data berdasarkan pertimbangan perorangan atau peneliti pada lokasi penelitian yang akan diamati dimaksudkan agar data yang diperoleh dapat memberikan estimasi yang akurat sesuai tujuan penelitian.

\section{Pengukuran kondisi terumbu karang}

Tujuan dilakukan pengukuran kondisi terumbu karang adalah untuk melihat gambaran luasan karang hidup serta jenis genus yang mendominasi di lokasi penelitian. Pengukuran dilakukan dengan menggunakan metode Line Intercept Transect (LIT) (English et al., 1997). Penelitian dilakukan pada dua lokasi yaitu stasiun I dan stasiun II. Panjang line transek adalah $50 \mathrm{~m}$, diletakkan sejajar garis pantai di kedalaman 1 meter dan 4 meter.

\section{Persentase penutupan karang}

Persentase penutupan karang mati, karang hidup, alga dan komponen lainnya dihitung dengan rumus (English et al., 1994).

$$
n_{i}=\frac{l_{i}}{L} \times 100 \%
$$


Keterangan:

$\mathrm{n}_{\mathrm{i}}=$ Persentase penutupan karang.

$\mathrm{l}_{\mathrm{i}}=$ Panjang total jenis karang.

$\mathrm{L}=$ Panjang transek garis (Line transect).

Kriteria penilaian kondisi terumbukarang berdasarkan KEPMEN LH No. 4 Tahun 2001 adalah :

1. Kategori buruk adalah $0-24,9 \%$

2. Kategori sedang adalah $25-49,9 \%$

3. Kateori baik adalah $50-74,9 \%$ dan

4. Kategori sangat baik/ memuaskan adalah $75-100 \%$

\section{Pengamatan densitas zooxanthellae}

Pengamatan densitas zooxanthellae dilaksanakan dengan cara memahat sebagian koloni rangka karang Acropora sp dengan menggunakan tang pemotong pada delapan koloni berbeda yang masing - masing diambil dari dua stasiun pengamatan di perairan terumbu karang Pulau Menjangan Kecil yaitu stasiun I dan stasiun II. Kemudian sampel dimasukkan ke dalam cool box yang diberi aerator dan kemudian dibawa ke laboratorium. Di laboratorium sampel disimpan dalam wadah kecil dengan air laut dan diberi aerator sebelum zooxanthellae diisolasikan atau dipisahkan dari badan karang.

Menurut Nordemar et al., (2003), konsentrasi zooxanthellae dalam polip karang dipergunakan sebagai variabel utama kajian ini. Berkenaan dengan pengukuran peubah ini, maka dilakukan urutan pekerjaan sebagai berikut :

- Mengambil sebagian spesimen karang Acropora sp (dengan luas 5-10 cm) dari sampel permukaan polip karang. Permukaan polip karang dengan luasan yang sama dicacah pelan dengan menggunakan mortal dan alu hingga hancur dan zooxanthellae lepas. Kemudian diletakkan dalam cawan petridis dan dihomogenasi dalam $10 \mathrm{ml}$ aquadest. Kemudian dituangkan kedalam botol sampel untuk di homogenasi dengan alat centrifiuges selama 10 menit dengan kecepatan 2500 - 3000 rpm untuk memisahkan supernatannya. Selanjutnya supernatannya dianalisis dengan menggunakan haemocytometer.

- Mengamati densitas zooxanthallae dengan menggunakan haemocytometer, dengan mikropipet yang diambil dari supernatan dan diletakkan di haemocytometer, kemudian diamati secara langsung dengan menggunakan mikroskop dengan pembesaran 10 x 10 . Jumlah zooxanthallae dihitung didasarkan kepada luas area

- $\quad$ Penghitungan Jumlah zooxanthellae Secara Langsung Menggunakan haemocytometer

Rumus menghitung jumlah sel/ml dalam kotak sedang adalah :

Jumlah sel/ml = jumlah sel x $2,5 \times 10^{6}$

Cara kerja penghitungan menggunakan kotak sedang (Nordemar et al.,2003)

$>\quad$ Membersihkan Petroff-Hauser Counting Chamber atau haemocytometer dengan alkohol $70 \%$ lalu keringkan dengan tisu;

> Meletakkan gelas penutup di atas alat hitung;

$>$ Menambahkan $\pm 50 \mu \mathrm{l}$ suspensi sel mikroba (kira-kira 1 tetes) dengan cara meneteskan pada parit kaca (sample introduction point) pada alat hitung. Suspensi sel akan menyebar karena daya kapilaritas. Pastikan bahwa ruangan penuh terisi dengan suspensi, ditambah beberapa kelebihan dalam saluran di sampingnya;

> Membiarkan sejenak sehingga sel diam di tempat (tidak terkena aliran air dari efek kapilaritas);

$>\quad$ Meletakkan alat hitung pada meja benda kemudian cari fokusnya pada perbesaran $10 \times 10$;

$>$ Melakukan perhitungan secara kasar apakah diperlukan pengenceran atau tidak. Jika dalam satu kotak sedang terdapat sel-sel yang banyak dan bertumpuk maka perhitungan akan tidak akurat. Jika demikian, maka diperlukan pengenceran; dan

Hitung sampel, paling tidak sebanyak 5 kotak sedang (lebih banyak lebih baik). Hasil perhitungan dirata-rata kemudian hasil rataan dimasukkan rumus untuk kotak sedang. Jika dilakukan pengenceran maka jumlah sel/ml dikalikan faktor pengenceran.

Analisis kimia terhadap kadar nitrat dan fosfat polip Acropora sp

Sampel polip karang Acropora sp diambil pada 2 Stasiun : titik 1 sampai dengan titik 8. Pada masingmasing titik diambil 1 buah sampel karang Acropora sp berukuran $\pm 10 \mathrm{~cm}^{2}$ serta dimasukkan kedalam cool box dan diberi label, kemudian dibawa kelaboratorium untuk dilakukan penanganan lebih lanjut. Sebagian contoh polip karang Acropora sp ditimbang dan kemudian dilakukan analisis kandungan nitrat dan fosfatnya.

\section{Analisis kimia terhadap kadar nitrat dan fosfat perairan}

Sampel air laut diambil pada 2 stasiun: titik 1 sampai dengan titik 8. Pada masing-masing titik diambil 2 botol sampel air sebanyak $100 \mathrm{ml}$ serta dimasukkan ke dalam botol sampel dan diberi label, sampel air untuk pengujian nitrat diawetkan dengan 5 tetes $\mathrm{H}_{2} \mathrm{SO}_{4}$, dan sampel air untuk pengujian fosfat dibekukan serta dimasukkan dalam cool box, kemudian dibawa ke laboratorium untuk dilakukan pengukuran menggunakan Spectrophotometer. 
Tahapan pengukuran nitrat dan fosfat air laut :

1. Preparasi Sampel

Preparasi sampel dilakukan dengan cara mengeringkan sampel polip karang menggunakan oven, kemudian menghaluskan karang dengan cara ditumbuk. Setelah itu melakukan analisis kimia kandungan nitrat dan fosfat.

Menurut Hutagalung dan Rozak (1997), ekstraksi sampel untuk analisis nitrat dan fosfat dengan cara menimbang 2 gram sampel dengan teliti dan dimasukkan kedalam botol. Kemudian ditambahkan larutan pengekstrak Bray I sebanyak $14 \mathrm{ml}$, kocok selama 1 menit. Lalu menyaring dengan kertas saring Whatman, hasil saringan siap untuk dianalisis nitrat dan fosfat dengan menggunakan prosedur kualitas air sebagai berikut:

2. Analisis nitrat

Analisis nitrat dilakukan dengan cara memasukkan $2 \mathrm{ml}$ air sampel yang telah disaring kedalam gelas piala, kemudian menambahkan $5 \mathrm{ml}$ brucin lalu diaduk. menambahkan $5 \mathrm{ml}$ asam sulfat pekat. Lalu membuat larutan blangko dari $5 \mathrm{ml}$ aquades. Kemudian membuat larutan standar nitrat yang sebelum pengenceran 100 ml menambahkan 20-30 ml aquades sampai tanda tera. Dengan larutan blangko dan dengan Spectrophotometer 0,000 absorbance dengan panjang gelombang $410 \mathrm{~nm}$, mengukur sampel dan larutan standar.

3. Analisis fosfat

Analisis fosfat dilakukan dengan cara memasukkan $2 \mathrm{ml}$ air sampel tersaring dan menambahkan $1 \mathrm{ml}$ Ammonium molybdate, kemudian diaduk. Lalu menambahkan 5 tetes $\mathrm{SnCl}$, setelah itu diaduk dan diamkan 10 menit dan sebelum 12 menit, mengukur air sampel dan larutan standar dengan Spectrophotometer 0,000 absorbance dengan panjang gelombang $690 \mathrm{~nm}$.

\section{Pengukuran parameter kualitas air}

Adapun data penunjang untuk mendukung penelitian ini adalah beberapa parameter kualitas air. Tujuan dari pengukuran parameter kualitas air ini adalah untuk memberikan gambaran tentang kondisi lingkungan penelitian. Pengukuran ini dilakukan satu kali di titik penelitian pada setiap stasiun. Rincian tentang jenis peubah dan metoda pengukuran faktor lingkungan pendukung ini adalah sebagaimana disajikan pada Tabel.

Tabel. Parameter Kualitas Air

\begin{tabular}{llcl}
\hline No. & \multicolumn{1}{c}{ Parameter } & Satuan & \multicolumn{1}{c}{ Alat } \\
\hline 1 & Temperatur & ${ }^{0} \mathrm{C}$ & Termometer \\
2 & Salinitas & $0 \%$ & Refraktometer \\
3 & $\mathrm{pH}$ & - & pH paper \\
4 & Oksigen terlarut & $\mathrm{mg} / \mathrm{l}$ & DO meter \\
5 & Kecepatan arus & $\mathrm{m} / \mathrm{s}$ & Current meter \\
6 & Kecerahan dan kedalaman & $\mathrm{Cm}$ & Secchi disk \\
\hline
\end{tabular}

\section{Evaluasi Data}

Untuk melakukan evaluasi data dipergunakan uji analisa regresi linier sederhana pada program SPSS 16.0 Menurut Hartono (2008), uji ini digunakan untuk memprediksi pengaruh variabel bebas (nilai total Nitrat dan nilai total Posfat) terhadap variabel terikat (densitas zooxanthellae pada polip karang acropora $\mathrm{sp}$ ).

\section{Hasil dan Pembahasan}

\section{Gambaran Umum Lokasi Penelitian}

Kepulauan Karimun Jawa secara geografis terletak pada posisi, $5^{0} 40^{\prime}-5^{0} 57^{\prime}$ LS dan $110^{0} 04^{\prime}-110^{0}$ 40’BT Kawasan Karimun Jawa pada awalnya merupakan kawasan cagar alam laut berdasarkan Keputusan Menteri Kehutanan No. 123/Kpts-II/1986 tanggal 9 April 1986. Kemudian melalui Surat Menteri Kehutanan No. 161/Menhut-II/1988 tanggal 23 Februari 1988, kawasan tersebut dinyatakan sebagai taman nasional. Setelah itu, melalui SK Menteri Kehutanan No. 78, Kpts-II/1999, tanggal 22 Februari 1999 ditetapkan sebagai taman nasional dengan nama Taman Nasional Karimun Jawa. Taman Nasional Karimun Jawa memiliki luas 111.625 Ha meliputi 22 pulau (BTNKJ, 2009). Pulau Menjangan Kecil terletak pada koordinat $05^{0} 53^{\prime} 10^{\prime \prime}-05^{0} 53^{\prime} 50^{\prime \prime} \mathrm{LS}$ dan $110^{\circ} 24^{\prime} 18^{\prime \prime}-110^{\circ} 49^{\prime} 40^{\prime \prime}$ BT dan memiliki luas 46 ha. Kepulauan Menjangan kecil memiliki iklim tropis yang di pengaruhi oleh angin laut yang bertiup sepanjang hari. Ekosistem terumbu karang menyebar hampir di seluruh gugusan pulau yang ada, terdiri dari tiga tipe yaitu: terumbu karang pantai (fringing reef), terumbu penghalang (barrier reef), dan goba (Istanto, 1998).

Lokasi sampling terdiri dari dua stasiun, stasiun I terletak pada koordinat S $05^{\circ} 53^{\prime} 15.06^{\prime \prime}$ dan E $110^{\circ}$ 24' 26.35", yaitu kawasan rataan terumbu karang kedalaman 2 meter dan stasiun II terletak pada koordinat S $05^{0} 53^{\prime} 17.56^{\prime \prime}$ dan E $110^{\circ} 24^{\prime} 23.12^{\prime \prime}$. kawasan rataan terumbu karang kedalaman 4 meter.

\section{Hasil pengukuran penutupan karang}

Hasil yang didapat dari pengamatan penutupan karang dengan metode line transek disajikan dalam Tabel 4 dibawah ini : 
http://ejournal-sl.undip.ac.id/index.php/maquares

Tabel 4. Penutupan Karang dan Persentase Pada Stasiun I dan Stasiun II dengan Metode Line Transek

\begin{tabular}{|c|c|c|c|c|}
\hline \multirow[t]{3}{*}{ Jenis penutupan } & \multicolumn{4}{|c|}{ Stasiun } \\
\hline & \multicolumn{2}{|c|}{ I } & \multicolumn{2}{|c|}{ II } \\
\hline & $\mathrm{cm}$ & $\%$ & $\mathrm{~cm}$ & $\%$ \\
\hline Karang hidup & 3680 & 73,6 & 3800 & 76 \\
\hline Karang mati & 910 & 18,2 & 740 & 14,8 \\
\hline Pecahan karang & 410 & 8,2 & 460 & 9,2 \\
\hline Jumlah & 5000 & 100 & 5000 & 100 \\
\hline
\end{tabular}

Analisis densitas zooxanthellae pada karang Acropora sp.

Hasil pengamatan densitas Zooxanthellae Acropora sp pada stasiun I dan stasiun II disajikan pada

Tabel 5 dibawah ini:

Tabel 5. Densitas Zooxanthellae di Polip Karang Acropora sp.

\begin{tabular}{ccc}
\hline No. & Titik Pengamatan & Densitas Zooxanthellae $(\mathrm{sel} / \mathrm{ml})$ \\
\hline 1. & Titik 1 & $44 \times 10^{6}$ \\
2. & Titik 2 & $78,5 \times 10^{6}$ \\
3. & Titik 3 & $61 \times 10^{6}$ \\
4. & Titik 4 & $69,5 \times 10^{6}$ \\
5. & Titik 5 & $67 \times 10^{6}$ \\
6. & Titik 6 & $57,5 \times 10^{6}$ \\
7. & Titik 7 & $69,5 \times 10^{6}$ \\
8. & Titik 8 & $63,5 \times 10^{6}$ \\
\hline
\end{tabular}

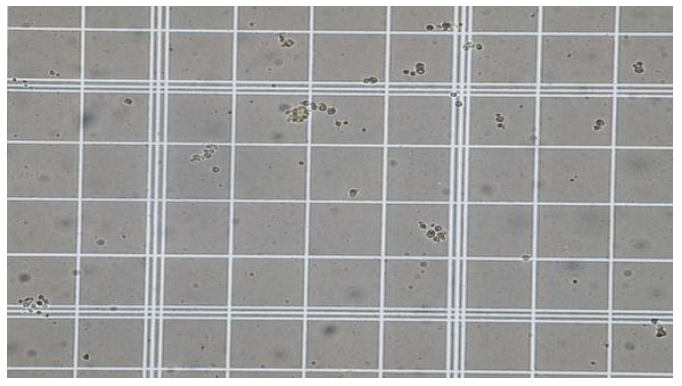

Gambar 12. Gambar Zooxanthellae pada Polip Karang Acropora sp (Sumber: Hasil Penelitian, 2013)

Tabel 6. Kandungan Nitrat dan Fosfat di Polip Karang Acropora sp. di stasiun I dan stasiun II

\begin{tabular}{cccc}
\hline No. & Titik Pengukuran & \multicolumn{2}{c}{ Jenis Nutrien } \\
\cline { 3 - 4 } & & Nitrat-NO3 $(\%)$ & Fosfat-PO4 $(\%)$ \\
\hline 1. & Titik 1 & 14.78 & 23.40 \\
2. & Titik 2 & 21.09 & 28.18 \\
3. & Titik 3 & 17.90 & 26.43 \\
4. & Titik 4 & 20.34 & 23.89 \\
5. & Titik 5 & 19.14 & 27.30 \\
6. & Titik 6 & 16.73 & 24.55 \\
7. & Titik 7 & 20.23 & 27.30 \\
8. & Titik 8 & 18.76 & 26.56 \\
\hline
\end{tabular}


Berikut adalah grafik hubungan antara kandungan total Nitrat dengan densitas zooxanthellae pada polip karang Acropora sp:

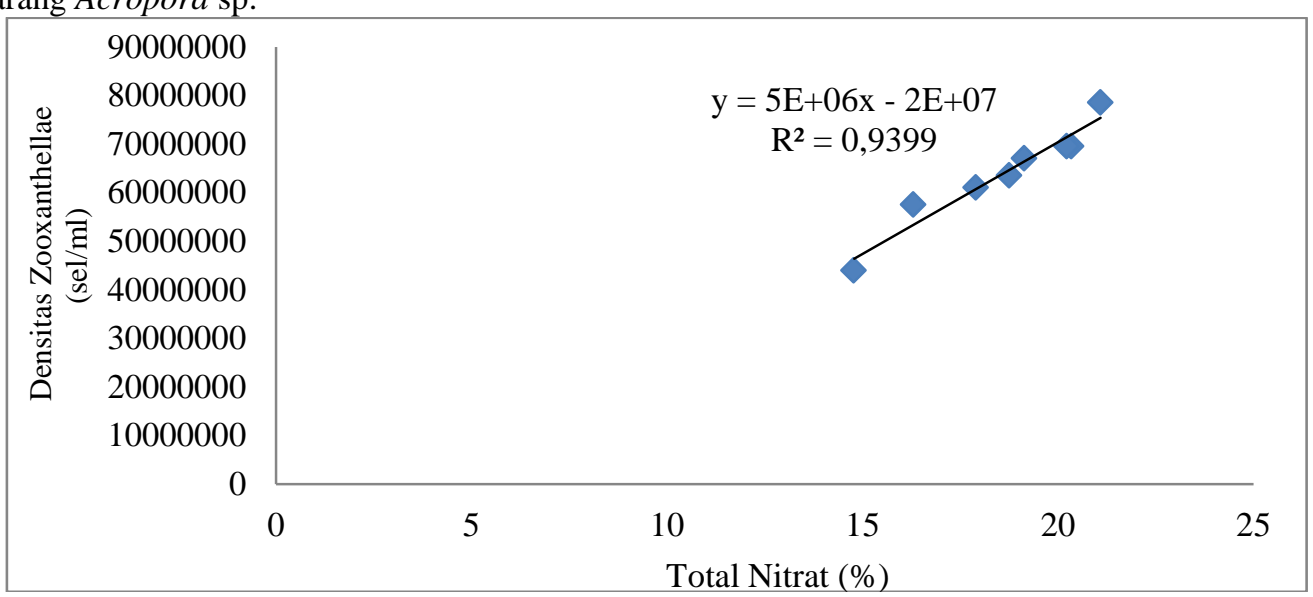

Gambar 13. Grafik Hubungan antar Kandungan Total Nitrat dengan Densitas Zooxanthellae pada Polip Karang Acropora sp.

Berikut adalah grafik hubungan antara kandungan total Fosfat dengan densitas zooxanthellae pada polip karang Acropora sp:

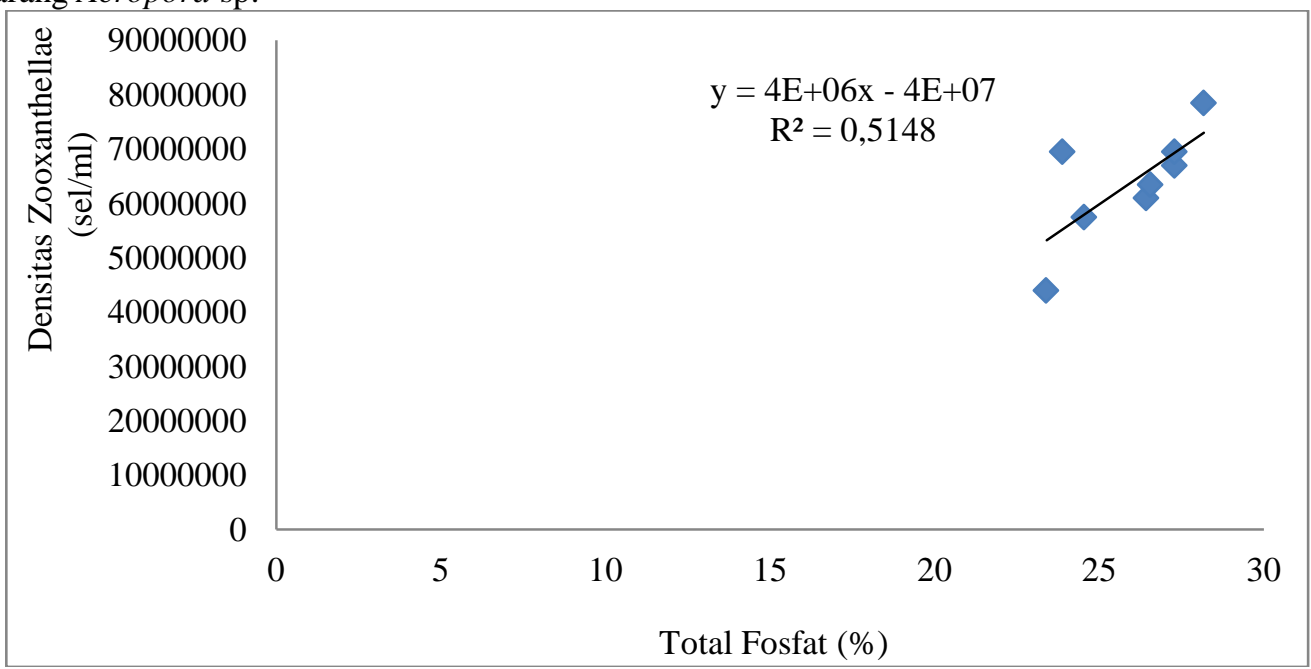

Gambar 14. Grafik Hubungan antar Kandungan Total Fosfat dengan Densitas Zooxanthellae pada Polip Karang Acropora sp.

\section{Hasil pengukuran parameter lingkungan}

Kisaran parameter kualitas perairan stasiun I di pulau Menjangan Kecil, Karimun Jawa dapat dilihat pada tabel dibawah ini:

Tabel 7. Nilai Parameter Kualitas Perairan di Pulau Menjangan Kecil, Karimun Jawa pada Stasiun I

\begin{tabular}{|c|c|c|c|c|c|c|c|}
\hline \multirow[t]{2}{*}{ No } & \multirow{2}{*}{$\begin{array}{c}\text { Parameter } \\
\text { Lingkungan }\end{array}$} & \multirow[t]{2}{*}{ Satuan } & \multicolumn{5}{|c|}{ Stasiun I } \\
\hline & & & Titik 1 & Titik 2 & Titik 3 & Titik 4 & Rata-rata \\
\hline 1. & Suhu Air & ${ }^{\circ} \mathrm{C}$ & 28 & 28 & 28 & 29 & 28 \\
\hline 2. & Suhu Udara & ${ }^{\circ} \mathrm{C}$ & 29 & 29 & 29 & 29 & 29 \\
\hline 3. & Salinitas & $\%$ & 32 & 32 & 32 & 32 & 32 \\
\hline 4. & $\mathrm{pH}$ & & 8,3 & 8,4 & 8,2 & 8,3 & 8,3 \\
\hline 5. & DO & $\mathrm{Mg} / \mathrm{l}$ & 4,5 & 4,5 & 4,7 & 4,3 & 4,5 \\
\hline 6. & Kecepatan Arus & $\mathrm{m} / \mathrm{s}$ & 0,15 & 0,17 & 0,24 & 0,18 & 0,15 \\
\hline 7. & Kedalaman & $\mathrm{m}$ & 1 & 1,3 & 1,2 & 0,8 & 1 \\
\hline
\end{tabular}

Kisaran parameter kualitas perairan stasiun II di pulau Menjangan Kecil, Karimun Jawa dapat dilihat pada tabel berikut : 
http://ejournal-sl.undip.ac.id/index.php/maquares

Tabel 8. Nilai Parameter Kualitas Perairan di Pulau Menjangan Kecil, Karimun Jawa pada Stasiun II

\begin{tabular}{llcccccc}
\hline No & Parameter & Satuan & \multicolumn{5}{c}{ Stasiun II } \\
\cline { 4 - 7 } & Lingkungan & & Titik 1 & Titik 2 & Titik 3 & Titik 4 & Rata-rata \\
\hline 1. & Suhu Air & ${ }^{\circ} \mathrm{C}$ & 29 & 29 & 28 & 28 & 28 \\
2. & Suhu Udara & ${ }^{\circ} \mathrm{C}$ & 27 & 26 & 28 & 27 & 27 \\
3. & Salinitas & $\% \mathrm{on}$ & 33 & 33 & 33 & 33 & 33 \\
4. & $\mathrm{pH}$ & & 8,5 & 8,5 & 8,6 & 8,4 & 8,5 \\
5. & DO & $\mathrm{Mg} / \mathrm{l}$ & 4,2 & 4,4 & 4,1 & 4,2 & 4,2 \\
6. & Kecepatan Arus & $\mathrm{m} / \mathrm{s}$ & 0,24 & 0,21 & 0,23 & 0,26 & 0,23 \\
7. & Kedalaman & $\mathrm{m}$ & 4 & 3,8 & 4,2 & 4 & 4 \\
\hline
\end{tabular}

\section{Penutupan karang}

Berdasarkan hasil pengamatan yang dilakukan pada saat penelitian ditemukan 6 jenis karang, yaitu Acropora sp., Fungia sp., Porites sp., Goniastrea sp., Montipora sp., Heliopora sp., berdasarkan perhitungan diperoleh nilai persentase penutupan karang hidup di lokasi sampling Pulau Menjangan Kecil, Karimun Jawa. Stasiun I sebesar 73,6\% dan Stasiun II sebesar 76\%. Menurut KEPMEN LH No.4 Tahun2001 kisaran nilai kelimpahan di lokasi sampling Pulau Menjangan Kecil termasuk kedalam kategori kondisi terumbu karang baik dan sangat baik. Nilai penutupan dead coral (DC) pada Stasiun I sebesar 18,2 \% dan Stasiun II sebesar 14,8\%. Kematian karang disebabkan aktivitas manusia yang melakukan pembuangan jangkar sembarangan tampa melihat karang yang ada di bawahnya. Hal ini sesuai dengan pendapat Suharsono (1996) bahwa masih banyak aktivitas manusia di daerah terumbu karang terutama pada saat pembuangan jangkar yang berakibat karang patah atau hancur pada saat kejatuhan atau ditariknya jangkar.

\section{Analisis densitas zooxanthellae karang Acropora sp}

Hasil dari penelitian menunjukkan bahwa densitas zooxanthellae pada lokasi penelitian berkisar antara $44 \times 10^{6}-78 \times 10^{6} \mathrm{sel} / \mathrm{ml}$ dengan rata-rata $63,25 \times 10^{6} \mathrm{sel} / \mathrm{ml}$. Zooxanthellae bersimbiosis dengan koloni karang. Koloni karang merupakan penyuplai terbesar kebutuhan zat anorganik untuk fotosintesis zooxanthellae. Oleh sebab itu, Moore (1991), mengemukakan bahwa status nutrisi bagi kebutuhan zooxanthellae dapat dijadikan sebagai indikator kesuburan terumbu karang. Zooxanthellae sama seperti biota laut pada umumnya memerlukan dukungan ketersediaan nutrien yang cukup. Tingkat kebutuhannya akan nutrien sangat berbeda atau berbanding terbalik dengan lingkungan eksternal di kawasan perairan terumbu karang, pada setiap waktu densitas zooxanthellae berfluktuasi, tergantung pada kualitas lingkungan perairan. Pada dasarnya keluar masuknya zooxanthellae terjadi setiap saat dari dalam tubuh karang. Jumlah zooxanthellae yang keluar tidak lebih dari $0,1 \%$ dari total standing stock simbion algae setiap hari.

\section{Analisis hubungan nitrat dan fosfat dengan densitas zooxanthellae pada karang Acropora sp.}

Setiap koloni hermatypic corals mengandung alga (zooxanthellae) yang hidup bersimbiosis dengan koloni karang. Polip karang merupakan habitat yang sesuai bagi zooxanthellae karena merupakan penyuplai terbesar kebutuhan zat anorganik untuk fotosintesis zooxanthellae. Zooxanthellae menerima kebutuhan nutrien penting seperti amonia, fosfat, dan CO2 dari sisa metabolisme karang (Bell, 1992). Karang memperoleh sebagian besar enerji dan nutrisinya melalui dua cara, yaitu melalui hasil fotosintesis oleh zooxanthellae atau secara langsung menangkap zooplankton dari kolom perairan ( Veron, 1995). Dari hasil pengamatan, didapatkan bahwa kandungan nitrat dan fosfat pada polip karang Acropora sp. di stasiun I dengan nilai rata-rata nitrat $18,52 \%$ serta posfat $25,47 \%$, dan dan stasiun II dengan nilai rata-rata nitrat 18,6 $\%$ serta posfat $26,42 \%$. Bila dihubungkan dengan nilai densitas zooxanthellae-nya maka hubungan yang didapat adalah semakin tingginya kandungan nutrien (dalam hal ini nitrat dan fosfat) pada karang tersebut maka makin tinggi pula densitas zooxanthellae pada suatu karang.

Untuk mengetahui hubungan antara nitrat dan posfat dilakukan analisis regresi. Sebelum dilakukan uji statistik dengan analisa regresi, terlebih dahulu dilakukan tes normalitas (Lampiran 5). Tujuan dilakukannya uji normalitas untuk mengetahui apakah suatu variabel normal atau tidak. Data yang di peroleh memiliki nilai signifikan sebesar 0.2 termasuk normal karena memiliki nilai signifikan $>0.05$, maka data dikatakan mempunyai distribusi normal. Data yang mempunyai distribusi yang normal merupakan salah satu syarat dilakukannya parametrik-tes. (Patria, 2005). Untuk mengetahui hubungan kandungan nitrat dan posfat pada densitas zooxanthellae di polip karang Acropora sp., dilakukan analisa regresi linier sederhana pada program SPSS 16.0 Data analisa yang diperoleh menunjukan besarnya persentase pengaruh variabel bebas (total nitrat) terhadap variabel terikatnya densitas zooxanthellae. Besarnya koefisien determinasi $\left(\mathrm{R}^{2}=0.939\right.$ pada Lampiran 5). Mengandung pengertian pengaruh total nitrat terhadap densitas zooxanthellae adalah 93,9 \% yang dapat ditarfsirkan bahwa variabel bebas X memiliki pengaruh kontribusi sebesar 93,9\% terhadap variabel $\mathrm{Y}$ dan $6,1 \%$ lainnya dipengaruhi oleh faktor-faktor lain diluar variabel $\mathrm{X}$. Data analisa yang diperoleh menunjukan besarnya presentase pengaruh variabel bebas (total posfat) terhadap variabel terikatnya densitas zooxanthellae. Besarnya koefisien determinasi $\left(\mathrm{R}^{2}=0.514\right.$ pada Lampiran 6), mengandung pengertian pengaruh total posfat terhadap densitas zooxanthellae adalah 51,4 \% yang dapat ditarfsirkan bahwa variabel bebas X memiliki pengaruh kontribusi sebesar 51,4\% terhadap variabel $\mathrm{Y}$ dan 
48,6\% lainnya dipengaruhi oleh faktor-faktor lain diluar variabel X. Penelitian di lingkungan perairan Pulau Menjangan Kecil, didapat kandungan nitrat dan fosfat yang tertera pada tabel 7 berikut ini:

Tabel 9. Kandungan Nitrat dan Fosfat pada Lingkungan Perairan Pulau Menjangan Kecil, Karimun Jawa

\begin{tabular}{cccc}
\hline \multirow{2}{*}{ No. } & Titik Pengukuran & \multicolumn{2}{c}{ Jenis Nutrien } \\
\cline { 3 - 4 } & & Nitrat-NO3 (mg/l) & Posfat-PO4 (mg/l) \\
\hline 1. & Titik 1 & 0.9 & 0.23 \\
2. & Titik 2 & 1.1 & 0.22 \\
3. & Titik 3 & 0.7 & 0.1 \\
4. & Titik 4 & 0.5 & 0.08 \\
5. & Titik 5 & 0.9 & 0.07 \\
6. & Titik 6 & 1 & 0.06 \\
7. & Titik 7 & 0.7 & 0.05 \\
8. & Titik 8 & 1.5 & 0.11 \\
\hline
\end{tabular}

Berdasarkan hasil penelitian, dilihat dari kandungan $\mathrm{NO}_{3}$ maka kondisi perairan Pulau Menjangan Kecil cenderung mesotrofik karena nilai kandungan $\mathrm{NO}_{3}$ pada perairan Pulau Menjangan Kecil berkisar antara 0,5 - 1,5 mg/l. Menurut Davis dan Cornwell (1991) dalam Effendi (2003), kadar $\mathrm{NO}_{3}$ yang lebih dari $0,2 \mathrm{mg} / \mathrm{l}$ dapat mengakibatkan terjadinya eutrofikasi (pengayaan) perairan, yang selanjutnya menstimulir pertumbuhan algae dan tumbuhan air secara pesat (blooming). Kadar Nitrat yang masih tergolong baik untuk kesehatan karang berdasarkan hasil penelitian adalah 0,040 mg/l (Bell, 1992).

Kondisi kandungan $\mathrm{PO}_{4}$ perairan Pulau Menjangan Kecil cenderung tinggi/eutrofik karena nilai kandungan $\mathrm{PO}_{4}$ pada perairan Pulau Menjangan Kecil berkisar antara 0,05 - 0,23 mg/l. Perairan laut yang mengalami eutrofikasi memiliki kadar fosfat $0,07 \mathrm{mg} / \mathrm{l}$. Kadar fosfor yang baik untuk kesehatan karang menurut Bell (1992), adalah sebesar 0,007 mg/l.

\section{Parameter lingkungan}

1. Kedalaman

Terumbu karang tidak dapat berkembang di perairan yang lebih dalam dari 50-70 meter. Kebanyakan terumbuh tumbuh pada kedalaman 25 meter atau kurang, karena zooxanthellae sebagai alga simbiotik memerlukan cahaya. Tanpa cahaya yang cukup, laju fotosintesis akan berkurang sehingga bersama dengan itu kemampuan karang dalam menghasilkan kalsium karbonat akan berkurang pula. Titik kompensasi untuk karang nampaknya merupakan kedalaman dimana intensitas cahaya kurang sampai 15-20\% dari intensitas permukaan (Nybakken 1992). Faktor kedalaman juga membatasi kehidupan binatang karang. Perairan yang jernih memungkinkan penetrasi cahaya bisa sampai pada lapisan yang sangat dalam, sehingga binatang karang juga dapat hidup pada perairan yang cukup dalam. Namun secara umum karang tumbuh baik pada kedalaman kurang dari 20 meter (Kinsman, 1964 dalam Supriharyono 2007). Distribusi vertikal terumbu karang hanya mencapai kedalaman efektif sekitar 10 meter dari permukaan laut. Hal ini disebabkan karena kebutuhan sinar matahari masih dapat terpenuhi pada kedalaman tersebut (Dahuri et al. 1996)

2. Temperatur

Hasil pengamatan di lapangan menunjukkan kisaran suhu perairan antara $28{ }^{0} \mathrm{C}$. Suhu ini masih baik untuk kehidupan dan perkembangbiakan terumbu karang dan masih sesuai dengan suhu yang dijumpai di lapisan permukaan laut yang normal. Dengan demikian temperatur lokasi penelitian masih dalam kategori baik bagi pertumbuhan terumbu karang beserta simbionnya. Supriharyono (2007) menyatakan, pertumbuhan karang optimal pada kisaran temperatur antara $25^{\circ} \mathrm{C}-32^{\circ} \mathrm{C}$.

3. Salinitas

Salinitas di daerah pengamatan adalah $32-33 \%$. Salinitas ini masih baik untuk pertumbuhan dan perkembangan karang yakni antara $25-40 \%$ Hal ini dikarenakan perairan berhubungan secara bebas dengan ditunjang arus yang cukup sehingga menunjang salinitasnya. Salinitas air laut tropis kurang lebih berkisar $35 \%$ Menurut Kinsman (1964) dalam Supriharyono (2007) menyatakan, binatang karang hidup subur pada kisaran salinitas antara $34-36 \%$. Namun pengaruh salinitas terhadap kehidupan karang sangat bervariasi tergantung pada kondisi perairan laut sekitar dan pengaruh alam seperti hujan. Berdasarkan angka toleransi tersebut, dapat dikatakan daerah penelitian dalam keadaan yang baik, yang memungkinkan biota karang dan simbionnya dapat hidup atau tumbuh optimal.

4. Derajat Keasaman $(\mathrm{pH})$

Derajat keasaman $(\mathrm{pH})$ di perairan Pulau Menjangan Kecil ini sebesar 8,3-8,5. pH ini masih sesuai dengan kriteria yang ditetapkan oleh Dahuri et al., (1996), yakni 6-9 untuk berbagai kepentingan. Derajat keasaman $(\mathrm{pH})$ di suatu perairan yang normal berkisar antara 8,0-8,3. Dengan demikian $\mathrm{pH}$ air laut di perairan Pulau Menjangan Kecil masih baik untuk kepentingan terumbu karang.

5. Oksigen Terlarut (DO)

Kadar oksigen terlarut di perairan Pulau Menjangan Kecil berkisar antara 4,2-4,5 mg/l. Kadar oksigen terlarut ini masih baik untuk terumbu karang. Kadar oksigen ini masih sesuai dengan kadar oksigen terlarut dilapisan permukaan laut yang normal umumnya. Menurut Sukarno (1995), kadar oksigen di permukaan laut yang normal berkisar antara 4,0-6,0 mg/l. Kadar oksigen di perairan kadarnya dipengaruhi oleh proses 
fotosintesis fitoplankton dan tumbuhan air yang lainnya berlangsung optimal karena ketersediaan cahaya matahari yang cukup. Proses lainnya yang mendukung tingginya kadar oksigen terlarut di perairan adalah di daerah pantai air dasar perairan yang mengandung banyak nutrien mudah teraduk ke badan air yang lebih atas sehingga nutrien dapat dimanfaatkan oleh fitoplankton untuk berfotosintesis.

6. Kecepatan Arus

Kecepatan arus yang diperoleh pada lokasi penelitian adalah $0,15-0,23 \mathrm{~m} / \mathrm{s}$. Arus sangat diperlukan oleh terumbu karang sebagai media yang membawa nutrien dan oksigen serta mencegah terjadinya sedimentasi yang tidak baik untuk pertumbuhan karang. Besarnya kecepatan arus akan mempengaruhi pertumbuhan biota karang, karena kuatnya arus akan memberikan suplai oksigen dan nutisi dalam air laut yang dibutuhkan oleh biota karang (Nybakken, 1992). Rachmawati (2001) menyatakan bahwa gelombang yang cukup kuat akan menghalangi pengendapan sedimen pada koloni karang. Struktur terumbu karang yang masif, cukup kuat menahan gelombang yang besar. Pada daerah yang terkena gelombang yang cukup kuat, bagian ujung sebelah luar terumbu akan membentuk karang masif atau bentuk bercabang dengan cabang yang sangat tebal dan ujung yang datar. Sebaliknya pada perairan yang lebih tenang akan berbentuk koloni yang berbentuk memanjang dan bercabang yang lebih ramping.

\section{Kesimpulan}

Berdasarkan hasil dan pembahasan, maka dapat diambil kesimpulan sebagai berikut :

1. Penutupan karang di perairan Pulau Menjangan Kecil stasiun I 73,6\% kategori baik dan stasiun II 76\% kategori sangat baik.

2. Nilai total nitrat di polip karang Acropora sp berkisar antara $14,78-21,09 \%$, dan nilai total fosfat di polip karang Acropora sp berkisar antara 23,4 - 28,18\% .

3. Densitas zooxanthellae di polip karang Acropora sp berkisar antara $44 \times 10^{6}-78 \times 10^{6} \mathrm{sel} / \mathrm{ml}$ dengan rata-rata $63,25 \times 10^{6} \mathrm{sel} / \mathrm{ml}$.

4. Nilai koefisien determinasi $\mathrm{R}^{2}$ antara total nitrat dengan densitas zooxanthellae sebesar 0,939 , dimana mengandung pengertian pengaruh total nitrat terhadap densitas zooxanthellae adalah sebesar 93,9\%. Koefisien determinasi $\mathrm{R}^{2}$ antara total fosfat dengan densitas zooxanthellae sebesar 0,514, dimana mengandung pengertian pengaruh total fosfat terhadap densitas zooxanthellae adalah sebesar $51,4 \%$. Semakin tinggi kandungan nitrat dan fosfat di dalam polip karang, maka semakin tinggi pula densitas zooxanthellae yang dikandungnya.

\section{Ucapan Terima Kasih}

Ucapan terima kasih ditujukan kepada Bapak Suyadi yang telah membantu penulis selama kegiatan penelitian. Ucapan terima kasih ditujukan pula kepada Ir. Prijadi Soedarsono, MSc., dan Churun Ain, S.Pi., M.Si., atas bimbingannya dalam penyusunan penelitian ini.

\section{Daftar Pustaka}

Basmi, J. 1999. Planktonologi : Bioekologi Plankton Algae. Fakultas Perikanan dan Ilmu Kelauan. IPB. Bogor. (tidak dipublikasikan)

Bell. 1992. Eutrophication and Coral Reef : Some Examles in The Great Barrier Reef Lagoon. Water Research.

Dahuri, R., J. Rais, S.P. Ginting dan MJ, Sitepu. 1996. Pengelolaan Sumber Daya Wilayah Pesisir dan Lautan Secara Terpadu. Pradnya Pratama, Jakarta.

Effendi, H. 2003. Telaah Kualitas Air bagi Pengelolaan Sumberdaya dan Lingkungan Perairan. Kanisius. Yogyakarta

English,S. Wilkinson, C. And Baker, V. 1994. Survey Manual for Tropical Marine Resources. Australian Institute of Marine Science, Townsville..

Institute of Marine Science, Townsville

Hartono. 2008. SPSS 16.0 Analisa Data Statistik dan Penelitian. Cetakan I. Pustaka Pelajar. Yogyakarta.

Hutagalung, H. P. dan A. Rozak. 1997. Metode Analisis Air Laut, Sedimen dan Biota. Buku 2. LIPI. Jakarta.

Istanto, D.M. 1998. Pengelolaan Taman Nasional Karimunjawa, Kaitannya dengan Pengembangan Kepulauan Karimunjawa. Lokakarya Pengelolaan Pulau-Pulau Kecil di Indonesia. Pulau Matahari.

Nybakken, J. W. 1992. Biologi Laut suatu Pendekatan Ekologis. Alih bahasa H.M. Eidman, Koesoebiono, D. G. Bengen, M. Hutomo dan S. Sukardjo. PT Gramedia Jakarta.

Rachmawati, R. 2001. Terumbu Buatan (Artificial Reef). Pusat Riset Teknologi Kelautan. Badan Riset Kelautan dan Perikanan. Departemen Kelautan dan Perikanan. Jakarta.

Suharsono. 1996. Jenis-Jenis Karang yang Umum Dijumpai di Perairan Indonesia. P3O. LIPI, Jakarta. 
Sukarno, R. 1995. Ekosistem Terumbu Karang dan Masalah Pengelolaannya. Materi Pendidikan dan Pelatihan Metodologi Penelitian Penentuan Kondisi Terumbu Karang. Pusat Penelitian dan Pegembangan Oseanologi LIPI dan Universitas Diponegoro. Semarang.

Supriharyono. 2007. Pengelolaan Ekosistem Terumbu Karang. Djambatan. Jakarta.

Veron, J. E. N.1995. Corals in Space and Time. University of NewSouth Wales Press. Australia. 